\title{
Janusowe oblicze natury. \\ Od Nordic Noir do serialu Kruk. Szepty słychać po zmroku
}

\begin{abstract}
Streszczenie
Autor artykułu zwraca uwagę na coraz większą popularność „,seriali nowej generacji” w Polsce. Skupia się przede wszystkim na analizie serialu Kruk. Szepty słychać po zmroku, którego akcja ma miejsce na Podlasiu. Analizuje tę produkcję pod kątem tego, jak ukazywana jest w niej natura i jaką pełni rolę względem głównego bohatera oraz głównego wątku narracji. Autor w swoich analizach wychodzi od metafory rzymskiego bóstwa - Janusa, a także odwołuje się do estetyki Nordic Noir, która miała znaczący wpływ na rozwój polskiego serialu kryminalnego. Prowadzone analizy pokazują, że o ile przesłanie skandynawskich seriali często związane było z krytyką społeczną, o tyle narracje, których miejsca akcji umieszczone są na polskiej prowincji (bardzo ważna rola natury), częściej mają wymiar metafizyczny, ekologiczny czy mitologiczny.
\end{abstract}

\section{Słowa kluczowe:}

polski serial kryminalny, Podlasie, Nordic Noir, Janus, natura

1 Tomasz Adamski, Instytut Studiów Kulturowych, Uniwersytet w Białymstoku, Polska, e-mail: t.adamski@uwb.edu.pl, ORCID ID: https://orcid.org/0000-0002-4702-5665. 


\begin{abstract}
The author of the article draws attention to the growing popularity of ,,new generation series" in Poland. He focuses primarily on the analysis of the series Raven. Whispers are heard after dark, which takes place in Podlasie region. Adamski analyzes this series in terms of how nature is portrayed in it and what role it plays, relative to the main character and the main plot of the narrative. In his analyzes, he starts from the metaphor of the Roman deity - Janus, and also refers to the aesthetics of Nordic Noir, which had a significant impact on the development of the Polish crime series. However, while the message of Scandinavian series has often been associated with social criticism, the narratives, whose places of action are located in the Polish province (a very important role of nature), more often have a metaphysical, ecological or mythological dimension.
\end{abstract}

\title{
Keywords:
}

Polish crime series, Podlasie, Nordic Noir, Janus, nature

\section{WPROWADZENIE}

Polski serial kryminalny zyskał bardzo wiele na popularności szczególnie w ostatnich pięciu latach. Produkcje, takie jak: 1983 (2018-), Ślepnq̨c od świateł (2018), Wataha (2014-), Belfer (2016) czy Kruk. Szepty słychać po zmroku (2018) pokazują, że polscy twórcy szukają swojego, własnego pomysłu na atrakcyjną kryminalną opowieść. W artykule chciałbym przyjrzeć się bliżej ostatniemu z wymienionych przeze mnie seriali i poddać go analizie pod kątem tego, jak ukazywana jest w nim natura i jaką pełni rolę względem głównego bohatera oraz głównego wątku narracji. By to zrobić, posłużę się metaforą rzymskiego bóstwa o imieniu Janus oraz odwołam się do estetyki Nordic Noir, która, po pierwsze, miała znaczący wpływ na rozwój polskiego serialu kryminalnego, a po drugie, to właśnie Skandynawowie pokazali, jak ważną rolę w opowieściach kryminalnych może odgrywać natura, która staje się nie tylko tłem, ale też jednym z głównych bohaterów kryminalnej intrygi.

Kruk, szepty słychać o zmroku to serial wyprodukowany przez telewizję Canal+ i w całości wyreżyserowany przez Macieja Pieprzycę². Bohaterem serialu jest

${ }^{2}$ Rzadko się zdarza, w tego typu produkcjach, by to jeden reżyser był odpowiedzialny za 
Adam Kruk, łódzki policjant, który dostaje zlecenie poprowadzenia śledztwa w rodzinnym Białymstoku. Powrót na Podlasie jest dla niego wyprawą w mroczną krainę dzieciństwa, które spędził w jednym z białostockich domów dziecka, gdzie wraz z innymi wychowankami był wykorzystywany seksualnie. Wydarzenia te odcisnęły mocne piętno na jego psychice, co przejawia się w uzależnieniu od leków uspokajających i licznych wizjach, jakie produkuje jego mózg. Jedną z takich wizji jest pojawiająca się postać Sławka - jego przyjaciela z domu dziecka, który materializuje się właśnie w momencie, gdy Kruk odstawia leki i udaje się na Podlasie.

\section{JANUS RAZY TRZY}

Odwołanie do Janusa, które jest zamieszczone w tytule, ma co najmniej trzy znaczenia. Po pierwsze, janusowe oblicze oznacza zmienny charakter czegoś lub kogoś bądź też dwa oblicza jednej sprawy. W przypadku moich rozważań dotyczyć to będzie nie tylko rozdwojonego wizerunku głównego bohatera, ale przede wszystkim swego rodzaju dwoistości, zmienności związanej z rolą, jaką w omawianej produkcji odgrywa natura. Otóż może być ona schronieniem dla tych, którzy przybywają z zewnątrz - z miasta, ale może też konotować zagrożenie jako przestrzeń, w obrębie której mają miejsce zbrodnia, przemyt, gwałt. Często jest to związane w faktem, że w takich miejscach (ostępach natury) łatwiej jest zatrzeć ślady, przez co trudniej wytropić przestępcę.

Janus był również uznawany za opiekuna drzwi, bram, przejść, mostów. A w przypadku serialu, który chcę poddać analizie, mamy do czynienia właśnie z taką metaforyczną bramą. To nie przypadek, że jedna część janusowego oblicza patrzy na Wschód, druga na Zachód. Kruk... jest produkcją, której akcja osadzona jest w północno-wschodniej Polsce, na Podlasiu. Jest to miejsce pogranicza, gdzie kończy się Unia Europejska, a zaczyna nieznany, barbarzyński, „zbrodniczy” Wschód, którego synonimem jest Rosja czy Białoruś. Maria Janion w swojej książce Niesamowita Słowiańszczyzna słusznie zauważa, że: „Starożytna opozycja cywilizacji i barbarzyństwa w świecie nowożytnym przełożyła się na opozycję »Zachodu« i »Wschodu«" (Janion, 2006, s. 165).

Ta „wschodniość” też jest znamionowana przez naturę, przez ujęcia przyrody nasuwające skojarzenia ze wschodnim/azjatyckim stepem (drugi odcinek i konna

całokształt serialu. Tak jest jednak w tym przypadku. Dlatego możemy traktować tę produkcję jako dzieło o charakterze autorskim. 
podróż Kruka ze Sławkiem) oraz przez powtarzające się ujęcia brzóz, tak charakterystyczne dla klasycznego rosyjskiego kina ${ }^{3}$. Ponadto w kontekście Janusa, jako figury odsyłającej nas do symboliki mostu - można zauważyć za Marcinem Całbeckim piszącym o Europie Środkowo-Wschodniej: „[...] w miejscu tym dokonuje się ciągłe zapośredniczenie i w szczególności dotyczy ono zetknięcia, swoistego mostu, jakim jest ta przestrzeń w odniesieniu do dwu kluczowych rozgałęzień tradycji europejskiej: odwołującego się do łacińsko-rzymskiego nurtu Europy Zachodniej i grecko-bizantyjskiego nurtu Europy Wschodniej” (Całbecki, 2013, s. 12). Ten sam autor zauważa również, że tym, co łączy mieszkańców Wschodu nie jest kolonizacyjny proces kulturowy, a właśnie „identyczność warunków naturalnych, »ekologiczna« wspólnota tej samej przyrody, która od swych świadomych mieszkańców - ludzi - wymaga podobnych form dostosowawczych, analogicznego systemu zachowań” (Całbecki, 2013, s. 90).

Po trzecie w końcu - Janus, od którego nazwę wziął styczeń, jest patronem zimy i wszelkich początków. Akcja analizowanego przeze mnie serialu ma miejsce późną jesienią, gdy widać już oznaki wkraczającej powoli zimy, ale nowy początek jest przede wszystkim związany z postacią głównego bohatera, który zanim zostanie ojcem i zacznie życie na nowo, musi zmierzyć się z duchami przeszłości.

\section{NATURA JEST WAŻNA, CZYLI CO ZAWDZIĘCZAMY NORDIC NOIR}

Od mniej więcej 2007 roku, czyli od momentu wydania trylogii Millenium ${ }^{4}$ napisanej przez Stiega Larssona, na całym świecie spopularyzowane zostało pojęcie Nordic Noir ${ }^{5}$. Mianem tym określa się literaturę kryminalną, filmy czy seriale,

3 Jako przykłady można podać filmy: Lecq żurawie, reż. M. Kałatozow (1957), Cichy Don, reż. S. Gierasimow (1957). Można też, w tym kontekście, sięgnąć do ścieżki dźwiękowej filmu Tlen I. Wyrypajewa (2009), gdzie pada znamienne zdanie (tłum. własne): „Nie ma rosyjskiego filmu bez brzóz".

4 S. Larsson, Mężczyźni, którzy nienawidzq kobiet, Wydawnictwo Czarna Owca, Warszawa 2008, S. Larsson, Dziewczyna, która igrała z ogniem, Wydawnictwo Czarna Owca, Warszawa 2009, S. Larsson, Zamek z piasku, który runq̨, Wydawnictwo Czarna Owca, Warszawa 2009.

${ }^{5}$ Nie będę tu definiował tego terminu, bo nie to jest celem tego artykułu. Więcej informacji na temat Nordic Noir można znaleźć między innymi w: K. Bergman, Swedish crime fiction. The making of Nordic Noir, Wydawnictwo Mimesis International, UK 2014, S. Peacock, Swedish crime fiction. Novel. Film. Television, Wydawnictwo Manchaster University Press, Manchester 2014, P. Arvas, A. Nestingen, Scandinavian Crime Fiction, Wydawnictwo University of Wales Press, Cardiff 2011, B. Forshaw, Death in a cold climate, Wydawnictwo Palgrave Macmillan, UK 2012, B. Forshaw, Nordic Noir. The Pocket Essential Guide to Scandinavian Crime Fiction, Film and TV, Wydawnictwo 
które powstawały w jednym z państw nordyckich. Wyznacznikiem tego typu narracji jest również to, iż obok prowadzonego śledztwa głównym przesłaniem tych opowieści jest krytyka społeczna. Nie ma tu miejsca na dokładną analizę tego fenomenu, zainteresowanych odsyłam do bogatej literatury na ten temat ${ }^{6}$. Chciałbym jedynie, na potrzeby tego artykułu, zaznaczyć, że jedną z cech konstytuujących Nordic Noir jest umieszczanie akcji tego typu powieści, filmów czy seriali poza centrum, a co za tym idzie, w otoczeniu dzikiej, „egzotycznej” przyrody, której piękno często kontrastuje z okrucieństwem opisywanej/filmowanej zbrodni. Pisze o tym między innymi Kerstin Bergman, autorka książki Swedish crime fiction. The making of Nordic noir (Bergman, 2014, s. 103). Otóż zauważa ona, że od wczesnych lat dwutysięcznych wzrosła liczba szwedzkich pisarzy kryminalnych, którzy odrzucili tradycję krytyki społecznej obecnej w powieściach Maj Sjöwall i Pera Wahlöö7. Umieszczali oni akcje swoich powieści w wiejskich, oddalonych od centrum lokalizacjach, gdzie dominowała natura i rzadko które ślady globalizacji czy zagrożeń zewnętrznego świata były obecne.

Już nawet powierzchowne spojrzenie na okładki skandynawskich powieści kryminalnych, plakatów do filmów bądź seriali określanych mianem Nordic Noir pokazuje, jak ważną rolę w obrębie tej estetyki odgrywa właśnie natura. Powtarzającym się motywem jest mroczny, zimny, pusty krajobraz, często przedstawiany w ciemnych niebieskawo-zielonych barwach, wywołujący w widzu nastrój określany mianem scandinavian gloom, któremu to nastrojowi bardzo blisko jest do poczucia melancholii. O ile w przypadku poprzednika Nordic Noir czyli filmu Noir, owa posępność, mroczność były związane z miastem jako siedzibą grzechu i panoszącego się bezprawia, tak w przypadku Nordic Noir, ów mroczny nastrój często przypisany jest prowincji i znajdującym się tam małym miasteczkom, które są umieszczone w otoczeniu dzikiej, tajemniczej przyrody (Hansen, Peacock, Turnbull, 2018, s. 223). Taki zabieg artystyczny możemy również odczytać jako zerwanie ze stereotypowym, romantycznym postrzeganiem pozamiejskiej natury, jako swego rodzaju idylli, ale też jest on ilustracją tego, że współczesna zbrodnia opuściła już granice miast i równie naturalnym środowiskiem staje się dla niej prowincja i natura. Najczęściej akcja tego typu opowieści ma również miejsce w pobliżu jakiegoś wodnego akwenu, przez co wodzie przypisywana jest złożona

Oldcastle Books, Chicago 2013, A. Nestingen, P. Arvas, Scandinavian crime fiction, Wydawnictwo University of Wales Press 2011.

6 Patrz przypis 5.

7 Autorzy serii o komisarzu Becku (1965-1975), która zapoczątkowała popularność skandynawskiego kryminału. 
symbolika (Hansen, Waade, 2017, s. 67-68). Ostatnie produkcje, takie jak Jordskott (2015-) czy Angelby (2015-) dla niej pokazują natomiast, że coraz częstszym zabiegiem jest również umieszczanie akcji w pobliżu wielkich obszarów leśnych, co bardzo często wprowadza do fabuł elementy supernaturalne czy mistyczne (Hansen, Waade, 2017).

Co ciekawe - konsekwencją takiego zabiegu jest zmiana przesłania, jakie niosą ze sobą tego typu historie. Morderstwo przestaje już być metaforą upadku społeczeństwa, czy efektem działalności jakiegoś syndykatu zbrodni, który opanował miasto.

Z czasem estetyka Nordic Noir stała się tak popularna, że przekroczyła granice państw nordyckich i rozprzestrzeniła się w całej Europie. Świadczyć o tym może książka Barry’ego Forshawa zatytułowana Euro noir (Forshaw, 2014) w której autor podaje przykłady tego typu produkcji w wielu państwach europejskich. Na potwierdzenie tej tezy wymienić można takie seriale, jak: Broadchurch (2013-2017), Pustkowie (2016-), Hinterland (2013-). Nic też dziwnego, że w pewnym momencie moda ta dotarła również do Polski. Początkowo przez adaptacje skandynawskich wzorców, jak choćby serial Pakt (2015-2016) oparty na norweskim pierwowzorze zatytułowanym Układ (2014-2016). Z czasem jednak polscy twórcy nabrali pewności siebie i zaczęli realizować własne pomysły (już drugi sezon serialu Pakt oparty był na oryginalnym polskim scenariuszu). W ten właśnie sposób powstały takie produkcje, jak: Belfer (2016-2017), Wataha (2014-), czy Kruk. Szepty słychać po zmroku (2018-).

Oczywiście, jeśli spojrzymy na polską i skandynawską kinematografię, inny jest punkt wyjścia, jeśli chodzi o kinematograficzne tradycje w prezentowaniu natury. Skandynawscy reżyserzy bardzo często sięgali po rodzimą literaturę, która ma długą i znamienitą tradycję w portretowaniu natury czy krajobrazu. Tradycję tę niejako przejęła współczesna proza kryminalna, a za nią film. Kerstin Bergman szukając egzemplifikacji tego zjawiska podaje przykład cyklu powieści o komisarzu Wallanderze autorstwa Henniga Mankella, gdzie autor poprzez liczne

8 Jedna ze szwedzkich wytwórni filmowych Yellow Bird ukuła nawet własne hasło reklamowe, które brzmi: „Zmieniamy bestsellery w blockbustery”. Warto również podkreślić w tym kontekście, że w Szwecji prawie od początków istnienia tamtejszej kinematografii wykorzystywano ujęcia natury (i to nie tej wykreowanej w studiu filmowym), by stworzyć kontekst dla opowiadanej historii bądź by scharakteryzować stan psychologiczny głównego bohatera. Jako przykład można podać filmy Victora Sjöströma - Terje vigen (1917), Banici (1918) czy Mauritza Stillera - Skarb rodu Arne (1919). 
opisy przyrody ilustrował stan psychiczny bohatera i postępy śledztwa. Innymi przykładami mogą być powieści Monsa Kallentofta czy Asy Larsson (Bergman, 2015 s. 85).

\section{KRUK... Z PERSPEKTYWY TWÓRCÓW SERIALU}

Już na podstawie wywiadów z twórcami serialu odnosimy wrażenie, że ulokowanie akcji tej produkcji na Podlasiu miało przemożny wpływ na jej ostateczny kształt. Reżyser Maciej Pieprzyca zauważa: „Wcześniej Podlasia nie znałem, czytałem o nim, podczas dokumentacji zacząłem je poznawać. To region mieszania się różnych kultur, niespenetrowany, jest w nim coś magicznego. W nim i w tych ludziach, którzy tam żyją, oni są blisko natury, ważne są dla nich wiara, obrzędy [...]” (Steciak, 2018). W innym wywiadzie podkreśla natomiast: „,...] coś z elementów tego regionu pokazaliśmy, na przykład odrobinę charakterystycznego dla tego miejsca realizmu magicznego - gdzie światy żywych i umarłych nawzajem się przenikają” (Steciak, 2018). W podobnym tonie wypowiadają się aktorzy. Marcin Bosak zauważa, że: „Podlasie to niezbadany obszar, to wszechogarniająca cisza. To miejsce ma magiczną moc, jest dzikie, oniryczne” (Tracewicz, 2018). Cezary Łukaszewicz natomiast dodaje: „Pamiętam, jak kręcąc serial, wstawaliśmy o 5.00 nad ranem i jechaliśmy pod granicę białoruską po wyboistej drodze, a potem lądowaliśmy w środku niczego, gdzie jest dziko, pięknie. Aż chciałoby się tak iść przed siebie, żeby nie było żadnych granic, tylko ty i przyroda. Podlasie jest melancholijne, tam czas się zatrzymał” (Tracewicz, 2018).

Z wypowiedzi tych wynika jasno, że twórcy charakteryzują Podlasie przez pryzmat tamtejszej natury, której przypisują specyficzne, magiczne właściwości. Czytając wywiady z twórcami, utwierdzamy się w przekonaniu, że serial ten byłby zupełnie inny, gdyby jego akcja miała miejsce, dajmy na to, na Śląsku czy na Kaszubach. Już w pierwszej scenie przyjazdu na Podlasie miejsce to jawi się widzom jako magiczna, zdominowana przez naturę kraina. Widzimy ogromne puste przestrzenie porośnięte dzikim, gęstym lasem. Brak jest jakichkolwiek znaków cywilizacji, a jeśli pojawia się samochód głównego bohatera, to zajmuje niewiele miejsca w kadrze i „ginie” przytłoczony przez naturę.

Warto również zwrócić uwagę, że tego typu spojrzenie na Podlasie, przez pryzmat przyrody, pokrywa się z recepcją tego regionu przez odwiedzających go turystów. Jak bowiem pokazują przeprowadzone badania (Popławski, Glińska, 2012), większość turystów wybierając Podlasie jako miejsce destynacji kieruje się właśnie jego walorami przyrodniczymi. 


\section{POWRÓT DO NATURY}

Jak zauważa Stougard Nielsen, bardzo charakterystycznym zabiegiem dla wielu opowieści sygnowanych mianem Nordic Noir jest powrót głównego bohatera do miejsca swego dzieciństwa, czego przykładem może być serial Jordskott (2015-2017) lub Norskov (2015-) (Nielsen, 2018, s. 214). Zazwyczaj bohater taki zamieszkuje jakieś „centrum”, a następnie w wyniku nagłych wydarzeń musi udać się na prowincję, skąd pochodzi, by tam rozwiązać kryminalną zagadkę i jednocześnie dowiedzieć się o sobie czegoś nowego. Zazwyczaj miejsce, które opuszcza, jest związane z cywilizacją, miastem, a miejsce, do którego jedzie, jest związane z prowincją, z naturą. Adam Kruk opuszcza centrum Polski - Łódź i zostaje wysłany na Wschód do Białegostoku. Twórcy serialu bardzo często za pomocą ujęć przyrody podkreślają różnice między centrum a peryferiami. O ile Łódź najczęściej charakteryzowana jest za pomocą ujęć we wnętrzach, nasuwających skojarzenia z cywilizacją (komisariat, mieszkanie Kruka, szpitalne korytarze, deptak w centrum miasta, ulice, po których jeżdżą tramwaje), o tyle Podlasie jest charakteryzowane za pomocą ujęć natury (wąska droga przecinająca zielony las, zielono-szare bagna z powtykanymi w nie biało-czarnymi brzozami, pagórkowate łąki czy wąska, wijąca się rzeka) ${ }^{9}$. Warto w tym kontekście zwrócić uwagę, że swego rodzaju decorem Podlasia staje się właśnie natura. Reinders zauważa, że decor nie jest nigdy dziełem przypadku, a wybierany jest spośród dobrze znanych ikon odwołujących się do lokalnej tożsamości, takich, które są rozpoznawalne i aktywują pewien rodzaj „turystycznego spojrzenia” (Hansen, Waade 2017, s. 32).

Dla Kruka powrót w miejsce swego dzieciństwa jest jednocześnie powrotem do natury. Musi do niej wrócić, by narodzić się na nowo i stać się pełnowartościowym ojcem. Te ponowne, symboliczne narodziny anonsuje nam już czołówka serialu. Najpierw widzimy ujęte z lotu ptaka las oraz rzekę, które są spowite gęstą mgłą. Potem kamera obniża swój lot, by pokazać pozbawione liści gałęzie i ciemnozielono-brązowe trawy, których widok kojarzy się z jesienią. Tego typu panoramiczne ujęcia miejsca akcji pokazujące lokalny krajobraz są często używane jako ujęcia ustanawiające, od których zaczyna się wiele seriali. Pełnią one rolę informacyjną, określają pewien nastrój, który ma odczuwać widz (w tym przypadku uczucie melancholii), ale też korespondują ze stanem psychicznym bohatera filmowej opowieści. Następnie widzimy postać mężczyzny, który próbuje się wydostać

9 Różnice między centrum a peryferiami obserwujemy również w trakcie licznych scen telefonicznych rozmów Kruka z ciężarną żoną, gdzie jest ona zawsze ukazywana w kontekście jakichś wnętrz, a Kruk na tle rozległych ujęć podlaskiej przyrody. 
zza czegoś w rodzaju grubej, przezroczystej folii. Widzimy jego zniekształconą twarz, dłonie i fragmenty ciał, które napierają na powierzchnię przezroczystego materiału, odciskając na nim swoje piętno. Scena ta przywołuje na myśl poród i chęć wydostania się płodu z łona matki. Jednocześnie jest to skontrastowane z jesiennymi ujęciami przyrody, która umiera, zanika, by zapaść w zimowy sen. Widzimy więc, że coś musi umrzeć, by coś innego mogło się narodzić. To ujęcia natury sugerują nam, co się stanie z głównym bohaterem.

Poza tym już samo nazwisko głównego bohatera (Adam Kruk) nasuwa nam skojarzenia z symbiozą świata ludzkiego i zwierzęcego. Warto w tym kontekście zwrócić uwagę, że za pomocą podobnej symbiozy zarówno Kafka, jak i Stasiuk charakteryzowali całą Europę Środkową. Marcin Całbecki zauważa bowiem, że: „[...] karnawał i ludowe średniowiecze, które aktualizują się w wizji Stasiuka we współczesnej Europie Środkowej, to przede wszystkim świat symbiozy ludzkiego i zwierzęcego, to regres i przezwyciężenie renesansowo-oświeceniowego ideału indywiduacji w imię powrotu do raju natury” (Całbecki, 2013, s. 312).

\section{JESIEŃ I MGŁA, CZYLI POLISH GLOOM}

Warto również zwrócić uwagę na fakt, że twórcy serialu celowo rozgrywają jego akcję jesienią. Ta pora roku bowiem odpowiada melancholii (Agger, Waade, 2018, s. 60-63), która wydaje się najlepszym określeniem na zjawisko określane mianem scandinavian gloom (Ferguson, 2016), które jest jednym z najważniejszych wyznaczników estetyki Nordic Noir. Ten melancholijny nastrój wykreowany jest za pomocą złożonych postaci, za którymi kryje się mroczna przeszłość, powolnego tempa narracji, rozległego jesiennego krajobrazu i muzyki przeplatanej ciszą (Agger, Waade, 2018, s. 61). Ponadto mroczną atmosferę podkreślają takie środki filmowe, jak desaturacja kolorów, niedoeksponowane ujęcia z preferencją do koloru niebieskiego, brązów i szarości. Często również powtarzają się ujęcia zachmurzonego nieba, a akcja ma miejsce późnym wieczorem, gdy na ziemię pada niewielka ilość światła (Agger, Waade, 2018, s. 28). Ta zbieżność „,skandynawskiego nastroju” z polską jesienią nie jest przypadkowa. Bardzo często akcja skandynawskich seriali toczy się właśnie jesienią (Hansen, Waade, 2017, s. 69). Pza tym z polskiej perspektywy ta pora roku przypomina najbardziej klimat, jaki spotykamy w skandynawskich produkcjach, takich jak Most nad Sundem (2011-2018) czy Forbrydelsen (2007).

W tym kontekście pamiętać również należy, że w polskiej tradycji listopad (w którym to miesiącu dzieje się akcja serialu) kojarzony jest z dniem Wszystkich 
Świętych i Zaduszkami, co oznacza, że do wspomnianej mrocznej atmosfery możemy dodać jeszcze elementy transcendentne. Nic dziwnego, że jednym z wizualnych lejtmotywów tego serialu są liczne ujęcia krzyży, cmentarzy (katolickich czy prawosławnych) oraz poukrywanych w wysokich żółtych trawach drewnianych rzeźb świątków. Uważna analiza wizualna serialu nasuwa nam również skojarzenia o równorzędności władzy „Ziemskiej” i „pozaziemskiej”. Wrażenie takie odnosimy, analizując sekwencję obrazów, w której zestawione są ze sobą ujęcie komisariatu i wzgórze z umieszczonymi na nim krzyżami.

Z jesienią związana jest również mgła, która bardzo często pokrywa miejsca akcji. Jednocześnie jest ona kolejnym elementem związanym z naturą, który dookreśla nam stan psychiczny głównego bohatera. Otóż, moim zdaniem, Kruk podświadomie tęskni za pewną formą jedności. Jego psychika, ze względu na wydarzenia z przeszłości, jest rozbita na dwie części, jak wizualne przedstawienia głowy Janusa. Mgła natomiast zamazuje granice, powoduje, że wszystko wydaje się takie samo, staje się jednością, przyczynia się do wytworzenia pewnego rodzaju dwuznaczności, powodując zawieszenie pewności, co do otaczającego nas świata (Agger, Waade, 2018, s. 73). Trudno nam rozpoznać, gdzie kończy się ziemia, a zaczyna niebo. Rzeczywistość miesza się z magią. Świat żywych, ze światem umarłych. Pomiędzy nimi znajdują się tylko...

\section{SZEPTUCHA I MULO}

Z dotychczasowych rozważań wynika, że w omawianym serialu przyrodzie przypisuje się wielką moc. Tak wielką, że „wdziera się” ona również do wnętrz przypisanych człowiekowi. Przykładem tego może być sekwencja, która ma miejsce w przydrożnym barze, do którego kilka razy trafiają bohaterowie serialu, by zjeść tradycyjnego schabowego i popić go kilkoma kieliszkami wódki. Gdy jednak oderwiemy wzrok od serwowanych tam kulinariów i uważnie przyjrzymy się wnętrzu, dostrzeżemy, że pełno tam brzozowych pni, gałęzi, fragmentów drzew. Pomieszczenie sprawia wrażenie, jakby było zaanektowane przez naturę. Również wielki drewniany dom, w którym zaczyna się akcja serialu, położony w środku lasu (osiem kilometrów od najbliższych zabudowań), zdominowany jest przez naturę, nie tylko z zewnątrz, ale i wewnątrz. Na drewnianych powierzchniach ścian wiszą bowiem myśliwskie trofea w postaci zwierzęcych łbów. Podobnie wygląda także wnętrze domu komendanta policji. Przyroda ma taką moc, bo jest związana z magią, czymś transcendentnym, wykraczającym poza ludzkie rozumienie (co ma siłę czynienia dobra, ale też przewidywania zła - świadczyć o tym może scena, 
w której Szeptucha przewiduje śmierć swojej wnuczki).

Wspomniane już przeze mnie autorki artykułu Melancholy and murder zauważają również, że z melancholią powiązana jest niesamowitość przez to, że w zwyczajnym z pozoru krajobrazie dostrzegamy coś niepokojącego (Agger, Waade, 2018). I tak jak we wnętrzach dostrzegamy niepokojącą moc natury, to podobne wrażenie sprawiają na widzu drewniane figury świątków poutykane na poboczach dróg, którymi przemieszcza się Kruk.

Najlepiej ów związek natury i magii uosabia jedna z bohaterek serialu, która jest Szeptuchą ${ }^{10}$, czyli kobietą, która łączy religię z zielarstwem, lecznictwem i parapsychologią. Filmowa Szetpucha żyje gdzieś w opuszczonym drewnianym domu pośród bagien, lasów i łąk. Korzysta z magicznych właściwości natury i potrafi za jej pomocą odczynić urok bądź wyleczyć złamaną rękę (jak to czyni za pomocą wody ze studni). Warto zwrócić uwagę, że podobnie do Szeptuchy w trakcie prowadzenia śledztwa zachowuje się Kruk. Tak jak ona wyszeptuje jakieś niezrozumiałe wyrazy i wodzi dłońmi w powietrzu, rysując sobie tylko znane figury. Szeptucha jako jedyna widzi również wyimaginowanego przyjaciela Kruka - Sławka, którego możemy określić mianem Mulo. Jest to określenie zaczerpnięte z języka Romów i oznacza kogoś w rodzaju żywego-umarłego, kogoś, kto wraca po śmierci, by rozwiązać sprawy, które nie zostały rozwiązane za jego życia.

\section{WNIOSKI}

Serial Kruk. Szepty słychać po zmroku jest tylko jednym z wielu przykładów tego, jak polscy twórcy, podążając za skandynawskim pierwowzorem, próbują nadać swoim produkcjom oryginalny, wyjątkowy charakter. Innymi przykładami seriali, w których przyroda odgrywa ważną rolę, mogą być, wspomniany już przeze mnie Belfer (sezon pierwszy) czy Wataha (oba sezony). Sam fakt uczynienia z przyrody głównego bohatera kryminalnej opowieści nie jest może nazbyt oryginalny, sposób jej pokazywania również mocno zapożyczony jest z estetyki Nordic Noir. To, co jest natomiast oryginalne w analizowanym przeze mnie serialu, to ukazanie natury charakterystycznej dla danego miejsca (Podlasia) i przypisywanie jej właściwości związanych z lokalnymi wierzeniami (Szeptucha, Mulo, figury podlaskich świąt-

10 Szeptunki to ludowe uzdrowicielki. Wyszeptują modlitwy, aby Bóg zesłał zdrowie na chorego. Są silnie związane z tradycją wschodnią i chociaż zazwyczaj korzystają z modlitw z obrządku prawosławnego, to ich praktyki oficjalnie nie są aprobowane przez kościół czy cerkiew. 
ków, zestawianie ze sobą symboliki związanej z religią katolicką i prawosławną). Tak jak z charakterem Kurta Wallandera (Wallander) najlepiej korespondują skaliste wybrzeża, z Sagą Noren i Marthinem Rhode (Most nad Sundem) - Kopenhaga, Malmö i most Öresund, z Rebrowem (Wataha) - bieszczadzkie lasy, z Adamem Krukiem (Kruk. Szepty słychać po zmroku) - mistyczna przyroda Podlasia. Symboliczną ciemność, którą Kruk nosi w sobie, widzimy odbitą w otaczającej go przyrodzie. I tak jak Kruk w rozwiązywaniu kryminalnych zagadek nie posługuje się tylko rozumem, ale czymś w rodzaju intuicji, przeczuć, tak również w obraz natury wpisany jest pewien rodzaj transcendencji, tajemnicy i magii.

Wspominałem już, że w produkcjach skandynawskich, w których przyroda odgrywa główną rolę, zmienia się przesłanie. Brak jest aspektów krytyki społecznej, a interpretacja często przesuwa się w stronę ekologii, transcendencji i mitu. W serialu Kruk... oba te podejścia zostały uwzględnione. Z jednej strony serial ma wymiar mistyczny związany właśnie z przyrodą Podlasia. Z drugiej strony obecna jest tu mocno krytyka społeczna, szczególnie krytyka zacofanej prowincji. Wydaje się, że Podlasie zostało przedstawione jako jedna wielka wieś. Bowiem za wszelkie zbrodnie odpowiedzialni są ludzie zamieszkujący te tereny, ci, którzy są mocno wpisani w lokalną społeczność: policjanci, wychowawcy, nauczyciele. Takie myślenie o Podlasiu pokrywa się z myśleniem Andrzeja Stasiuka o całej Europie Środkowej. „W ujęciu tego autora ten region Europy jawi się niczym gigantyczna wieś, a zachowania jej mieszkańców bliskie są mentalności feudalnego chłopa z czasów poprzedzających odkrycia geograficzne XIV i XV wieku” (Całbecki, 2013, s. 311).

\section{Bibliografia}

Arvas, P., Nestingen, A. (2011). Scandinavian Crime Fiction. Cardiff: University of Wales Press.

Bergman, K. (2014). Swedish crime fiction. The making of Nordic Noir. UK: Mimesis International.

Bergman, K. (2015). The Captivating Chill. Why Readers Desire Nordic Noir. Scandinavian-Canadian Studies, 22.

Całbecki, M. (2013). Zapośredniczona tożsamość. Tematy środkowoeuropejskie a polska literatura współczesna. Gdańsk: Wydawnictwo Uniwersytetu Gdańskiego.

Ferguson, R. (2016). Scandinavians. In Search of the Soul of the North. London: Head of Zeus.

Forshaw, B. (2012). Death in a cold climate. UK: Palgrave Macmillan.

Forshaw, B. (2013). Nordic Noir. The Pocket Essential Guide to Scandinavian Crime Fiction, Film and TV. Chicago: Oldcastle Books. 
Forshaw, B. (2014). Euro noir. The pocket essential guide to European crime fiction, film and TV. UK: Pocket essential.

Hansen, K.T., Peacock, S., Turnbull, S. (2018). European television crime drama and beyond. Switzerland: Palgrave European Film and Media Studies.

Hansen, K.T., Waade, A.M. (2017). Locating Nordic Noir. From Beck to the Bridge. Switzerland: Palgrave European Film and Media Studies.

Janion, M. (2006). Niesamowita Słowiańszczyzna. Kraków: Wydawnictwo Literackie.

Larsson, S. (2008). Mężczyźni, którzy nienawidzq kobiet. Warszawa: Czarna Owca.

Larsson, S. (2009). Dziewczyna, która igrała z ogniem. Warszawa: Czarna Owca.

Larsson, S. (2009). Zamek z piasku, który runq̨. Warszawa: Czarna Owca.

Nestingen, A., Arvas, P. (2011). Scandinavian crime fiction. Chicago: University of Wales Press.

Peacock, S. (2014). Swedish crime fiction. Novel. Film. Television. Manchester: Manchester University Press.

Popławski, T., Glińska E. (2012). Wyróżniki tożsamości województwa podlaskiego w opinii turystów. Ekonomiczne Problemy Usług, 85. Pobrane z: http://bazhum.muzhp.pl/ media//files/Ekonomiczne_Problemy_Uslug/Ekonomiczne_Problemy_Uslug-r2012-t-n85/Ekonomiczne_Problemy_Uslug-r2012-t-n85-s227-242/Ekonomiczne_Problemy_Uslug-r2012-t-n85-s227-242.pdf.

Steciak, M. (2018). Maciej Pieprzyca: blizny przypominają nam, że coś wydarzyło się naprawdę. Pobrane z: https://kultura.onet.pl/film/wywiady-i-artykuly/maciej-pieprzyca-blizny-przypominaja-nam-ze-cos-wydarzylo-sie-naprawde-wywiad/qf294zv.

Tracewicz, J. (2018). Jest co najmniej sześć powodów, za które można pokochać serial Kruk. O produkcji opowiadajq jej twórcy. Pobrane z: https://www.spidersweb.pl/ rozrywka/2018/03/17/kruk-canal-plus-wywiady/.

\section{Filmografia i serialografia}

1983 (2018-)

Angelby (2015-)

Banici (1918). V. Sjöström (reż.)

Belfer (2016)

Broadchurch (2013-2017)

Cichy Don (1957). S. Gierasimow (reż.)

Forbrydelsen (2007)

Hinterland (2013-)

Jordskott (2015-)

Kruk. Szepty słychać po zmroku (2018)

Leca żurawie (1957). M. Kałatozow (reż.)

Most nad Sundem (2011-2018)

Norskov (2015-)

Pakt (2015-2016)

Pustkowie (2016-) 
Skarb rodu Arne (1919). M. Stiller (reż.)

Ślepnąc od świateł (2018)

Tlen (2009). I. Wyrypajew (reż.)

Terje vigen (1917). V. Sjöström (reż.)

Układ (2014-2016)

Wataha (2014-)

Wallander (2005-2013) 